\title{
The Coming of Age of
}

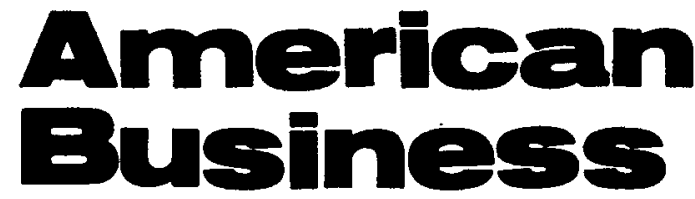

THREE CENTURIES OF ENTERPRISE, 1600-1900

by Elisha P. Douglass

With this masterful synthesis of the patterns of the nation's business development Elisha P. Douglass makes a major contribution to the study of American business and economic history. In a single narrative he brings together an unprecedented account of the development of leading business enterprises from the colonial period to the beginning of the twentieth century.

620 pages

$6 " \times 9 "$

$\$ 15.00$

THE UNIVERSITY OF NORTH CAROLINA PRESS

Chapel Hill, North Carolina 27514

\section{Finance and Economic Development in the Old South}

\section{Louisiana Banking, 1804-1861}

George D. Green. This analytical history of banking and finance in antebellum Louisiana uses modern economic theory to expand and revise the traditional interpretations of the role of financial institutions in early American history. The author demonstrates that the so-called evils of "paper money" and "wildcat banking" have been greatly overemphasized, while the role of banking in the development of cities, regions, and the nation as a whole has been either rejected or misunderstood. $\$ 8.75$

\section{Stanford University Press}


PATLRNALSM AND

PROTEST: Southern Cotton

Mill Workers and Organized

1.61601, 1875.1905

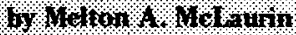

Uatitersit, of Sonth Alailina

$\$ 11.00$
This study offers evidence to refute the entrenched view that southern mill workers rejected the overtures of organized labor, and shows how management's shrewd use of social, economic, and political pressures suppressed serious organizational efforts in the South until World War I..

(Contributions in Economics and

Economic History, No. 3)

\section{New Books for the Historian}

BUSINESS AND POLTTLES WVAMERIC A FROM THE ACE OF $14 \mathrm{CKSON}$ TO THE CIVIL WAR; The Career

Biograptiy of

W. 1. Corcoran

$101010,00101,101012$

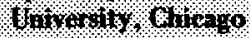

$\$ 13.50$
The complex combination of factors that shaped the financial and political policies of the U.S. during the 1840s and $1850 \mathrm{~s}$ is shown to be inexplicably entwined with the activities of the entrepreneur, W. W. Corcoran.

"... Well written and thoroughly researched (the notes and bibliography take up more than 150 pages), this original study by a competent academician will appeal to students of finance, economic and business historians, and to American historians interested in the role of business in politics."-Choice

(Contributions in Economics and Economic History, No. 4)

THE BEOLINE ANB. ABOL WION OF NEGRO SI.AVERY IN VENEZUELA. 18201854

610111010 mbidi

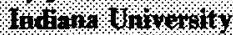

41.008

"Both scholar and informed layman will find this volume worthy of attention. . . The research is very good; the bibliographic and footnote references extensive and helpful. . . . The importance of Lombardi's study lies in its expansion of the geographic scope of studies on slavery into a country where slavery was of small economic importance and in its contribution to the long overdue revision of the thesis that slavery was more paternalistic in Latin America than in North America."-Choice
(Contributions in Afro-American and

African Studies, No. 7)

Brought together in one place for the first time, these essays by one of America's most astute political historians focus on such matters as the bitter slavery controversy in the territories and the factional conflict over a transcontinental railroad to the Pacific, as well as on other crucial social, political, and economic issues in the pre-Civil War period.

(Contributions in American History, No. 7)

TOOORORGANIZTHONS

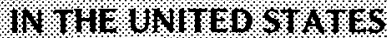
$01011 \% 180 \% \% 115801 \%$

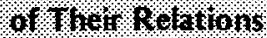

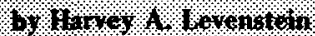

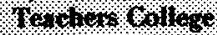

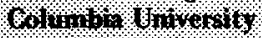
$\$ 1700$
The first thorough treatment of the relationship that developed between Mexican and United States labor organizations from the rise of the Mexican trade union movement in 1907 to the present.

(Contributions in American History, No. 13) 


\title{
THE HISTORY OF AMERICAN MANAGEMENT
}

\author{
Selections from the \\ Business History Review \\ Edited $E$ with an Introduction by \\ JAMES P. BAUGHMAN \\ Harvard Graduate School \\ of Business Administration
}

Original essays which view in historical perspective the key problems faced by managers of large-scale American enterprise. The emphasis is on "Big Business" covering the period from 1850 to 1950. Focuses on volatile questions and dramatic incidents in the business world. The essays give substantive information about historical events and provide for discussion of the real world versus the ideal world. Presents sufficient data to provide stimulating discussions about each selection.

(38926-2) 264 pp., cloth $\$ 5.95$

Orders are processed faster if Title and Title Code appear on your order.

For an approval copy, write Box 903

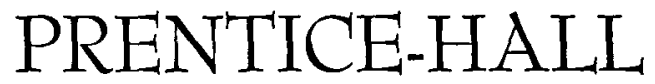

Englewood Cliffs, New Jersey 07632 